\title{
TAX POLICIES AND PRACTICES OF MONEY TAX REVIVAL IN SOVIET RUSSIA (1921-1924) AND THEIR RELEVANCE
}

\author{
Valentina M. Pushkareva \\ Institute of Economics and Entrepreneurship, \\ Moscow, Russia
}

\begin{abstract}
The author analyzes the USSR monetary practices and policies during the period of monetary taxes revival, which was the primary foundation for USSR tax and industrialization financial budget. The research was done by analyzing tax reforms in the works of Russian leading scientists of the NEP period: M. I. Bogolepov, N. P. Bryukhanov, P. P. Hensel, I. M. Kulisher, F. A. Menkov, P. V. Mikeladze, I. I. Reingold, I. I. Sokolnikov, V. N. Tverdokhlebov, L. N. Yurovsky. The author demonstrates that tax revival was entirely determined by the state of financial management in the country after the collapse of the Soviet Russia military communism period. The application of such tax tools as replacement of surplus-appropriation with the natural tax; introduction of the first nationwide monetary tax - tax on trade in the form of patent and equalization charges, the income tax on companies' revenues, excises is described in detail. The author concludes that Soviet Russia was creating its financial management for industrialization, which was matching the historical task of the ruling party - to build socialism. The revival of the monetary tax system started with tough and plain from the construction point of view direct and indirect tax forms. However, the elasticity of the first monetary taxes provided the budget with essential tax income in a short period. The analyzed results of 1921-1924 tax policy and practice allowed to demonstrate their relevance for solving urge economic problems of modern Russia. Tax building experience of the USSR is similar to the Russian Federation reindustrialization tasks (IT technologies). Relevant tax policies and practices of the NEP period allow to indicate certain aspects of modern tax policy and practice adaptation to the formation of internal investment sources in the period of transition to technological and innovative model of Russian economy
\end{abstract}

KEYWORDS Fiscal policy, money taxes, inflation, taxation principles, direct taxes, excise taxes, tax design, industrialization, reindustrialization (IT), fiscal efficiency

\section{HIGHLIGHTS}

1. Tax revival was entirely determined by the state of financial management in Soviet Russia after the collapse of the military communism period

2 . The revival of the monetary tax system started with tough and plain tax forms from the construction point of view

3. Soviet Russia was creating its financial management for industrialization based on the tax tools of the twenties of the last century

4. The experience of 1921-1924 tax policy and practice might be relevant to solve some urge economic problems of modern Russia 


\title{
НАЛОГОВАЯ ПОЛИТИКА И ПРАКТИКА ВОЗРОЖАЕНИЯ АЕНЕЖНЫХ НАЛОГОВ В СОВЕТСКОЙ РОССИИ (1921-1924) И ИХ АКТУААЬНОСТЬ
}

\author{
В. М. Пушкарева \\ Институт экономики и предпринимательства, \\ 2. Москва, Россия
}

\begin{abstract}
АННОТАЦИЯ В статье анализируются политика и практика Советской России (СССР) в период возрождения денежных налогов. Это послужило фундаментом для налогового бюджета и финансовых ресурсов в ходе индустриализации СССР. Исследование проводилось на основе анализа налоговых реформ, представленного в трудах ведущих ученых России периода новой экономической политики: М. И. Боголепова, М. Г. Бронского, Н. П. Брюханова, П. П. Гензеля, И. М. Кулишера, Ф. А. Менькова, П. В. Микеладзе, И. И. Рейнгольда, Г. Я. Сокольникова, В. Н. Твердохлебова, Л. Н. Юровского. В работе показывается, что возрождение налогов после краха налоговой системы в Советской России периода военного коммунизма всецело определялось состоянием денежного хозяйства страны. Подробно описывается применение таких налоговых инструментов, как замена продовольственной разверстки натуральным налогом; введение первого общегосударственного денежного налога (промыслового налога в виде патентного и уравнительного сборов); введение подоходно-поимущественного налога, подоходного налога от прибыли предприятий и акцизов. В результате исследование, сделаны выводы о том, что в 1920-е гг. XX в. Советская Россия создавала финансовую систему для индустриализации страны, что соответствовало исторической задаче правящей партии - строительство социализма. Восстановление денежной налоговой системы началось с точки зрения конструкции с грубых и примитивных прямых и косвенных форм налогов. Однако эластичность первых денежных налогов принесла бюджету в короткие сроки необходимые доходы. Рассмотренные итоги налоговой политики и практики 1921-1924 гг. позволили обозначить их актуальность для решения безотлагательных проблем экономики современной России. Опыт налогового строительства в СССР созвучен задачам Российской Федерации по реиндустриализации (IT-технологии). Актуальность налоговой политики и практики советского периода позволяет обозначить определенные аспекты адаптации современной налоговой политики и практики к формированию внутренних источников инвестиций при переходе России к технологической и инновационной модели экономики
\end{abstract}

КЛЮЧЕВЫЕ СЛОВА Налоговая политика, денежные налоги, инфляция, принципы налогообложения, прямые налоги, акцизы, конструкция налога, индустриализация, реиндустриализация (IT), фискальная продуктивность

\section{ОСНОВНЫЕ ПОЛОЖЕНИЯ}

1. Возрождение налогов после краха налоговой системы периода военного коммунизма определялось состоянием денежного хозяйства Советской России 2. Восстановление денежной налоговой системы началось с грубых и примитивных с точки зрения конструкции форм налогов

3. На основе налоговых инструментов в 20-е гг. прошлого столетия в Советской России была создана финансовая основа индустриализации

4. Опыт налоговой политики и практики 1921-1924 гг. может быть использован для решения безотлагательных проблем экономики современной России

The revival of taxes in Soviet Russia after the collapse of the tax system in the period of military communism was entirely determined by the state of the monetary system of the country as an external factor. On the other hand, the tax system in the same quality influenced the monetary sphere. The tasks of the NEP tax and monetary policy, as in no other period of Russian history, could be solved effectively only in mutual connection and conditionality. 
The hyperinflationary state of the money economy in the RSFSR for a long time, beginning in 1918, was a powerful brake in the restoration of the national economy, tax system, and state budget. Prof. F. A. Menkov, assessing the financial activities of the Soviet government, believed that excessive issue of paper money led to a complete breakdown of public finance and the entire economic life. "The improvement of monetary circulation is possible via the balance of government expenses and revenues. Only taxes can be the largest government income under current conditions" [1, p. 63].

People's Commissar of Finance G. Ya. Sokolnikov, realizing the state of affairs, set the task "...to build some tax system in the shortest possible time... to avoid the complete collapse of the monetary system..." [2, p. 117].

G. Ya. Sokolnikov linked the transition entirely to the monetary levying of agricultural taxes with the possibility of completing the monetary reform in his report "Program of Financial Recovery" at the 3rd session of the Central Executive Committee of the USSR on 9/11/1923: “In connection with the transition of a single agricultural tax to money, there is a possibility of ending the monetary reform" [3, p. 151].

G. Ya. Sokolnikov stressed that the monetary reform was prepared by two years of budgetary and taxation work in his report "How to Consolidate the Monetary Reform" at the financial meeting on June 2, 1924.

With the completion of the monetary reform, the monetary system was restored, which could ensure the receipt of taxes to the budget in hard currency, having provided stability to the budgetary system of the USSR. A. M. Gordin gave a final assessment of the tax and monetary reforms: "It was the calculation for the health-improving effect of the monetary reform which let start its implementation with an unavoidable budget deficit. In 1922/23 - the treasury issue accounted for $26.9 \%$ of the state income, $1923 / 24-5.5 \%$. This was one of the biggest achievements not only for the budget, but also for the whole economy of the Union" [4, p. 222].

"Severe and straightforward" N. P. Bryukhanov continued the tax system formation started by G. Ya. Sokolnikov. He wrote in 1927, "that the principles of building a tax system and taxation apparatus were established from 1921 to $1923 . . . "$ [5, p. 5]. If in 1921 the task was to survive and save the new system, then in 1926-1927, it was necessary to urgently seek budget revenues in order to provide financing for industrialization. In both cases, there was the same question from the point of view of the Soviet party leadership: "To be or not to be socialism in the USSR"?

The tax instrument (tax in kind) was the first and the only correct, which initiated restoration of the financial system, that played a decisive role as the "link through which the whole chain could be pulled out", restore the country's economy and prove the viability of Soviet Power. The new radical decree on the replacement of the food surplus with a natural tax was issued on March 21, 1921. In accordance with the resolution of Party Congress X, unlimited surplus-appropriation was replaced by a solid tax - tax in kind. It made almost a half of the surplus-stock. The abolition of surplus-appropriation and the introduction of tax in kind opened the way for trade development, which was the centripetal force for restoring the national economy of the country.

Prof. L. N. Yurovsky made the political and economic assessment of tax in kind introduction. "The turn from military communism began after 1921 ... with the replacement of surplus-appropriation with tax in kind. This replacement meant recognition of peasant's private property on the products of their labor, and at the same time their right to offer these products on the market" [6, p. 178]. Recognition of private property was a fundamental departure from the previously adopted documents on universalization of the economy.

The ratio of direct and indirect taxes is one of the scientific principles of tax system building. Prof. P. P. Hansel wrote that 
in NEP conditions preference had to be given to indirect taxes.

The emphasis on indirect taxes was made due to the lack of conditions for direct taxation development. P. P. Hansel wrote that "the more dispersed the national income is, the more inevitable is the role of indirect taxation, which is inevitable for the USSR - because coverage of broad masses by direct taxation is difficult to achieve in practice" [7, p.103]. G. Ya. Sokolnikov was forced to admit that "we ran ahead in the area of direct taxation". Instead of "destroying indirect taxes", as Soviet authorities believed, they had to step back from the Party principles and follow the path of indirect taxation due to severe financial circumstances.

"The research of the first period of financial economy restoration demonstrates how plain and tough this work was, especially at the first stages. But one must admit that ... it was necessary to build ... from scratch ... in 1921, not only the taxation apparatus did not exist, but also the national economic objects, which could be subject to taxation, were just outlined. The national economy, perhaps on four-fifths as far back as 1922, remained natural. The financial economy was at least half natural, because it was based on natural tax" [6, p. 196-197].

The restoration of the monetary system began with rough (indicative) and primitive (simplified) in terms of the construction, direct and indirect forms of taxes. There were good reasons for this. "Choosing these tough forms in the field of direct and excise taxation is not accidental and is caused by the entire situation in economy and taxation abilities of the population at that time" [8, p. 98]. "Weak adjustment of the pay machine and complete lack of data to determine the taxability of various categories of taxpayers makes one turn to very primitive methods of taxation" [9, p. 34].

On the other hand, the elasticity of the first money taxes brought much needed tax revenues to the budget in a short period. "The most tough tax, levied on all population groups, was still better than emission tax..." [8, p. 98].
By the decree of the All-Russian Central Executive Committee of July 26, 1921, the first nation-wide money tax was tax on trade, "in an apparently rude form, which corresponded to the commercial and industrial activity that began in 1921" [1, p. 63]. Tax on trade was introduced on the turnover of private industrial and commercial enterprises, and later state enterprises.

In comparison with new taxes, for instance income and property tax, there were no any special problems to levy tax on trade, because it had been habitual to pay in Tsarist Russia since 1898. But this did not apply to state enterprises which referred that it does not make sense to transfer money from one state pocket to another. "In 1921 tax on trade was $49 \%$, excise tax was $2.4 \%$, local taxes were $42.1 \%$ in the total amount of tax revenue" [9, p. 42-43].

Changes of 1922-1923 were aimed at improving the construction of tax on trade, overcoming the difficulties in determining company turnover, problems of trusts, syndicates, mixed societies, etc. taxation. Since 1923, not only commercial and industrial enterprises and establishments have been imposed by commercial taxes, but also single-hand crafts and trade classes were indicated in the special list. Because of the complex construction of the tax, consisting of two separate parts, tax calculation was also carried out separately: payment for the patent fee and the rate of equalization were set.

Patent fee was levied on issuing a patent for the right to commercial and industrial activity. The price of the patent was determined by the category and location of the enterprise. Trade enterprises were divided into five categories, industrial into 12. The price of the patent for each category was differentiated by company's location: there were Moscow and five territorial belts outside of Moscow. The first belt included Leningrad, Kharkov, Kiev, Odessa and Rostov-on-Don.

The second part of the commercial tax is equalization fee, which was levied once per half a year on the turnover of the enterprise for the previous half a year. There 
were 11 recognized types of turnover depending on the enterprise character.

Initially, the normal rate of equalization was $3 \%$ of turnover and the same for the local budget. Circular of July 25, 1923 by People's Commissariat of Finance simplified tax on trade, which by establishing a differential equalization fee. The detailed classification of commercial and industrial enterprises was developed with respect to the percentage of their equalization taxation. The rate of differential equalization was established for wholesale trade, retail and petty trade. The wholesale trade was taxed approximately $50 \%$ lower than retail and petty; The prevailing salary for the first was $1 \%$ of turnover, for the second $-1.5 \%$ [10, p. 39-40].

Due to the imperfection of equalization fee calculation and as a result of tax inspectors' authority abuse (they were arbitrarily increasing the sum of equalization fee) the phenomenon of one company multiple taxation occurred. On January 18, 1923, the USSR Council of People's Commissars issued the Decree on the Provisional Rules of Taxation for the equalization of state trusts, syndicates and combines, jointstock and mixed companies, mutual credit societies, banks and cooperative unions, at the request of state industrial enterprises, which partially solved the problem of multiple taxation. The provisional rules were in effect until 1925/26. Changes in taxation on trade were followed by the increase of its role in state budget income. In 1923/24, according to M. P. Bryukhanov, the share of tax on trade in direct taxes was $27.6 \%$ (the second in rank after agricultural tax) [11, p. 32-33]. The decree of the All-Russian Central Executive Committee and the Council of People's Commissars on February 11, 1922 introduced a civil tax such as the per capita tax levied in Tsarist Russia before abolition of serfdom. The tax rates were roughly differentiated depending on payer's social affiliation: 50 kopecks (for workers and employees up to grade 9), 1 rub. (for other workers and employees) and 1 rub. 50 kopecks for all other citizens. This was the initial form of personal money tax, which was levied twice in 1921 on the adult able-bodied population. "In financial terms, it was very productive, because it gave 10 million rubles in gold in less than one year. Despite the rough form of this taxation (though it is not worse than tax on salt and some excises), its success cannot be denied, especially since its universality caused increased demand for money in large mass of the peasant population and thereby contributed to the temporary consolidation of Soviet Power" [9, p. 34].

With the abolition of civil taxes by Decree in November 16, 1922, income and property tax was introduced on city residents and legal entities of a commercial and industrial nature, with the exception for state and cooperative companies cancelling general tax at the same time. The new regulation on income and property taxation of November 12, 1923, significantly restructured it. Taking the new regulation into consideration income and property tax substituted labor tax, the general tax on high salary rates. The tax was unified and simplified, which led to the improvement of the taxation techniques. The taxation was differentiated depending on tax payer's category: 1) taxation on wage labor; 2) taxation on independent farms; 3 ) taxation of persons owning independent companies and capitals.

Income - property tax by decree on November 12, 1923 was built on the system of bit-and-pay taxes similar to Prussian class tax. The tax rate was composed of a solid and additional salary. The additional salary meant that the tax would be progressive and this progression would primarily affect the well-off strata of the population. The allocation of three categories of taxpayers was thought out and justified in accordance with the principle of universality in taxation. G. Ya. Sokolnikov declared in the Report at the Third Session of the Central Election Commission on November 9, 1923: "It's impossible to levy it (income and property tax. $-V$. P.) only on the bourgeoisie... Therefore, The Council of People's Commissars made a decision that tax payers are both persons having wage labor as the source of existence, and persons who earn their livelihood from independent economy and labor" [3, p. 151]. Paying income and 
property tax by the working class was the sign of justice towards peasants, who paid agricultural tax. The new tax structure was significantly improved, especially as a result of the introduction of solid and additional salaries system.

But it was far from perfection: in practice, the payers' income was established neither according to average norms, nor on the basis of checking declarations, which was foreseen by class income tax; an unjustifiably high scale of taxation was established for legal entities.

The method of additional property taxation was poorly justified, and there were no prerequisites for a normal property tax at that time, therefore, the taxation was quite arbitrary. In general, the scale of taxation itself was characterized by high rates. In conditions when the tax authorities were not technically prepared to levy such a complex system as the general tax, and tax payers did not reach that level of consciousness and upbringing to honestly declare their true incomes, moderate rates were needed. Such conclusions on the imperfection of the income-property tax were made in 1924 by P. P. Hansel. The Decree of December 12, 1923 abolished the mandatory submission of declarations for most taxpayers because of its inefficiency: "The declaration is submitted twice, the examination of the declaration is a complicated matter. The first are being checked during half a year, and the others for the second half of the year are already coming. Other taxes, more complex (commercial tax, agricultural tax) are associated with an even greater time spending" [12, p. 43].

In 1923, the income tax was introduced at the rate of $10 \%$, and then $20 \%$ share of enterprises profits.

When constructing the income and property tax the prerequisite was the principle of certainty in taxation: "The tax from September 1923 is $1 \%$ per of $150-200$ rubles income, $12 \%$ per 4000 rubles. (The establishment of rates in gold (gold rub.)) is a significant advance over the method in the first half of 1923, because now the payer knows in advance how much he should pay and whether he is able to reduce all his receipts to gold rubles" [12, p. 42]. In
1924 the income and property tax was reformed into income tax [13, p. 45].

"Direct taxes, including income tax after World War I, took the dominant position in the tax system of Western countries. Income taxation "justified" itself in all countries, revealing an amazing elasticity. Never in history, had its rates reached such heights as in England and the United States. Neither the increase in rates was remarkable, nor that its revenues grew almost proportionally to these increases, reaching \$ 800 million in America, and in England to 399 million pounds in 1921-1922. This elasticity is a huge fiscal advantage of income taxation compared to consumption taxes (highlighted in italics by V. P.)" [14, p. 77].

Unlike Western countries, a limited basis for taxable income was a serious obstacle to the development of income taxation in the USSR. Despite this, the USSR People's Commissariat of Finance gave a very promising assessment of income and property tax in 1924: "In 1924 revenues of income and property tax grow, so it is already becoming one of the most serious foundations of our state budget" [15, p. 202].

E. M. Kulisher considered that the most important event in the tax sphere in 1923 was the establishment of a single agricultural tax by Decree of May 10, 1923. Agricultural tax was imposed on the peasantry, which was $3 / 4$ of the population of the USSR at that time. Replacing the natural tax with a single agricultural tax is an important step towards simplifying the tax system. The importance of simplifying the tax on the peasantry was in the fact that all direct taxes on the peasantry were replaced by a single tax. Universalization of agricultural tax simplified the way of paying taxes in the countryside, but on the other hand, it required raising the professional level of tax authorities and the will of the state. I. I. Rheingold briefly and capacitively estimated the importance of single agricultural tax: "In the history of taxes, it is hardly possible to find another example of such a vivid implementation of the class principle" [16, p. 125].

The position of an unattainable leader in direct taxation was kept by single ag- 
ricultural tax only for two budget years $(1923 / 24,1924 / 25)$, in 1925-1926 it was "caught up" by commercial tax.

In 1923, rental tax was introduced from new direct taxes, which did not bring the expected income and was excluded from the classification of the state revenues of the USSR.

The Decree of November 11, 1922, established the collection of tax on inheritances and donations from January 1, 1923. Inheritance in accordance with the USSR Civil Code was allowed both by law and by will, but was limited to direct descendants (children, grandchildren and greatgrandchildren) and a surviving spouse of the deceased, and also disabled and indigent persons actually in full support of the deceased at least one year before death. If the total value of the inheritance (after deducting documented debts, etc.) exceeded 10,000 gold. rubles, then all the surplus passed to the state; the inheritance according to the will could be transferred to the state; the share of the heir who renounced the inheritance, and all escheated property passed to the state. Due to strict inheritance restrictions in the USSR, the hereditary tax didn't have fiscal significance.

Indirect taxation began with the introduction of excise duty on grape and other wines. With the introduction of the excise on wine, alcohol and spirits in 1922, state revenue from food grew to such an extent that they immediately took the first place in the excise income of the unified state budget of the USSR in 1923-1924. In 1923-1924, the share of the excise tax on food was $17.2 \%$ [11, p. 32-33].

Other basic excises (from alcohol, salt, oil products, beer, shells, sugar, tea and coffee, yeast and candles) were put into effect during 1922. The isadvantages of the indirect taxation system were corrected by a more intensive taxation on items of sufficient consumption.

Excise on tobacco and linen products was established by Decree of the Council of People's Commissars on 21 November 1921. In 1923 the excise tax on tobacco products underwent a change: it came back returned to the former form of excise on finished products from the taxa- tion of raw materials. Then, a system of a medium-duty excise was established for a pound of tobacco and a thousand cigarettes. At the end of 1924 the Decree of the Central Executive Committee and the Council of People's Commissars dated October 3, 1924 abolished the average excise duty due to the objections of the tobacco industry. The system of the average excise tax prevented the production of different types of tobacco products. Simultaneously with the cancellation of the medium-term excise tax, the marginal prices for tobacco products were introduced. Revenues from tobacco excise increased by 2.2 times in 1924-1925, compared with the previous year, and their share in income from indirect taxation reached $11.2 \%$, yielding only excise on food and sugar [11, p. 32-33]. The growth of excise income in general, which was observed in the 1920s, was due not only to the maximum taxation rates, but also to the significant dynamics in excisable goods consumption, including tobacco products.

Excise on salt is an old and "popular" indirect tax in Western countries and Russia, which once gave large revenues to the treasury. Salt excise in France was introduced in 1345, the excise tax on salt was constantly raised in England from the first half of the 18th century, until its abolition in 1825 . In 1868 salt tax was $6.8 \%$ of the total amount of indirect taxes in Tsarist Russia. In 1880 salt tax was abolished. The famine of 1891-1992 forced the Ministry of Finance to even raise the issue of canceled taxes, including salt tax, but the State Council did not approve such a decision of the Ministry of Finance.

By Decree of February 23, 1922, after a 40-year hiatus, the excise tax on salt was restored, which covered the widest sections of the population, including the peasantry. According to I.I. Rheingold, the share of excise tax on salt was $13.9 \%$ in the total amount of excise income in $1922 / 23$ fiscal year, this is the fourth place after excise taxes on sugar, drinks and tobacco products [16, p. 144]. The excise on salt was abolished in April 1, 1927 by the Decree of the USSR Central Executive Committee. 
The excise on oil products was established by a Decree on March 9, 1922. Oil, kerosene, carbide and lubricating oils were subject to taxation. Natural crude oil and opaque oil products were free from excise. The excise was paid in cash for the release of products outside the factory, and in Baku, Batum and Grozny - for the release beyond the respective oil regions. Oil products imported from abroad were imposed in excess of the customs duty.

I. I. Rheingold estimated the role of petroleum excise in the total income from indirect taxation at $10.5 \%$ in 1922/23, which indicated its importance [16, p. 145]

The excise tax on sugar was established by the Decree in April 21, 1922, a clear dividing line in the taxation of sugar was drawn between private and public sectors of the economy. The grace period was granted only to state enterprises. In $1922 / 23$, excise tax on sugar was the first in rank among other excises, its share was $21.7 \%$ [16, p. 144]. In connection with this I. I. Rheingold noted a low level of sugar consumption in Soviet Russia in comparison with Western countries. Especially little sugar was consumed in the countryside, where the normal consumption of sugar meant that the family lived in abundance. In some cases, sugar in the countryside was a luxury item. And in these conditions, sugar was still a product of export abroad. The size of the excise tax on sugar as an object of mass consumption highlighted the extreme financial needs of the Soviet state.

Since 1923, the government of the USSR began to vigorously improve excise taxation, which continued until the tax reform in1930. The problem of excise taxes was constantly discussed by the leading scientists of the country P. P. Hansel, P. V. Mikeladze, M. G. Bronsky, I. I. Reingold, I. M. Kulisher. The political nature of the issue made it so relevant. How to ensure a symbiosis of indirect taxes and the construction of socialism, without departing from the class principles and providing them with more than $60 \%$ of the revenues of the USSR budget? The flexibility of excise policy and its, "fiscal productivity" (P. P. Hensel) in many respects were due to the degree of application of differentiated rates. Excise rates were set either on the unit of the object of taxation, or as a percentage of the price of the excisable product. Only the first method was used in the USSR in the 1920s. For example, 4 rubles. per a pood of sugar, 22 kopecks. per a pood of salt.

In the 1920s differentiated rates of excise taxation were widely used in the USSR. Differentiated rates were established in excises on alcoholic beverages, tea, tobacco and textiles. The principle of rates differentiation achieves fiscal results, if this differentiation is carried out according to grades or prices of excisable goods. The experience of the USSR on the introduction of differentiated excise rates stated to use in the excise policy of the West.

The new $19^{\text {th }}$ type of indirect tax in the USSR was the excise tax on textiles. The excise on textile products was first introduced by Decree in February 28, 1923. Excise was imposed on yarn, silk and semisilk fabrics, imported yarn and fabrics, and articles made of them.

In terms of "fiscal productivity", the excise tax on textile products in 1923-1924 occupied the third place, giving the way to excise on food and sugar. But from 19241925 and through 1927-1928, the fiscal effect decreased to $6.3-6.4-6.1 \%$ in the total amount of excises, though at the same time it was stable.

A new period of development of the system of excise taxation of textiles begins in autumn 1924. When problems in textile industry appeared, the drawbacks in the excise design became obvious. I. I. Rheingold wrote in 1930 that the basic question "how to levy excise - on yarn or finished products" had not yet been resolved [16, p. 159]. Consequently, the textile excise did not overcome the disadvantages of its design until the tax reform of 1930, when all excises collected in the USSR were converted into the single universal excise - turnover tax.

The restoration period of the USSR tax system (1921-1924) consisted of two stages. The initial stage was from 1921 to 1923. General principles for tax system construction and tax administration or- 
ganization were established in the period from the middle of 1921 to 1923.

"In total, there were 25 types of taxes in effect (except for natural tax) in 1922: 5 were direct taxes, 13 were indirect, and there were 7 types of duties. Thus, the construction of the tax system was finished in rough by the end of 1922, the main taxes were declared" [16, p. 52].

The successful implementation of tax measures became possible with the development of the national economy: "Financial legislation enjoyed growth of money economy, trade and industry development and the beginning of population property differentiation in order to overtake new objects of taxation and more skillfully approach those objects that had already managed to get into the sphere of its attention" [6, p.192].

The work on the formation of the tax system was conducted with great strain. In 1922/ 23 the tax system underwent serious changes. P. P. Hansel pointed out "the amazingly rapid development of our tax system" [9, p. 16].

M. I. Bogolepov named the three factors of increasing tax revenues in 1923. "First, due to the "natural" growth of the national economic income, second and third - due to the improvement of tax construction and collection machine" [17, p. 17-18].

L. N. Yurovsky, by careful comparison of the tax revenues for the period of 1922/ 23 and 1926/27 budget years, came to the conclusion that "it becomes clear how significant was the step taken during the initial period of financial sector restoration of" [6, p. 193].

The final stage of the recovery period one can call 1923/24, when the tax system was developed as a system of taxes and which, in the main, preserved the tax exemptions of the pre-war system (1914), but new taxes were already declared and levied on (in 1914 there was no single agricultural tax in Tsarist Russia, and there was still no vodka monopoly in Soviet Russia).

"The tax system of the Soviet Union is becoming now more or less complete. We have a system, on the one hand, of direct, on the other - of indirect taxes. Our direct taxes provide $55 \%$ of tax revenues. We came to the system of 4 whales: 4 direct taxes: single agricultural tax in the countryside, income and property in the cities, on trade and rent taxation. Single agricultural tax includes the elements of income and property tax, on the other hand it includes an element of rental taxation. There are elements of income and property taxation in tax on trade.

So, we have two main types of direct taxation: income and property and rental. This system of direct taxes is a great achievement of our revolution" [15, p. 201-202].

It should be emphasized that the "system of direct taxes" at that period in Soviet Russia corresponded to the world tendencies of increasing the share of direct taxes in state budget revenues, as V. N. Tverdokhlebov wrote in his book "The Newest Financial Problems (1914-1923)". Professor of Moscow University F. A. Menkov, assessing the results of the recovery period, wrote: "The extensive period of taxation development of the Soviet Power is over, the period of unification and intensification of the USSR tax system" began [1, p. 64]. The period of unification and intensification ended with a radical tax reform in September 1930.

The results of tax policy and practice (1921-1924) allow to identify their relevance for solving urgent problems of modern Russia economy.

In the $20^{\text {th }}$ years of the last century, Soviet Russia created the financial system for the industrialization of the country, which corresponded to the historical task of the ruling party to build socialism.

Modern Russia is once again going through hard times. The country has to go through global tests of a historical nature. There are strategic tasks comparable in scale, complexity and depth with the distant 20-ies of the XX century. "In the coming years, our country will have to carry out a radical renewal of its economic system, corresponding to those challenges and changes that are occurring before our eyes in the world social and economic or$\operatorname{der}^{\prime \prime}[18$, p. 5]. The main internal factor of recession and stagnation of Russian econ- 
omy is "the exhaustion of the economic growth model of the 2000s..." [18, p. 7].

In an interview to the Central Television of China, Chairman of the Government of the Russian Federation, D. A. Medvedev stressed that "Russia entered the period of re-industrialization, which is connected with the development of new economy, new industries based on innovations, on IT technologies". The solution of this task requires structural reforms primarily in the state (budget) sector. "Effective fiscal policy (including tax policy. $-V$. P.) is an indispensable condition for the economy to adapt to new realities" [18, p. 19].

The revival of the tax system of Soviet Russia was carried out in accordance with the world-recognized scientific principles of taxation. The peculiarity was in the fact, that the Soviet government, when implementing scientific principles, combined them with a rigid class approach.

Modern tax policy requires adaptation of scientific principles of taxation to the conditions of Russian economy reindustrialization. Urgency of the social approach in transition to market economy strengthens its significance considering the new historical reality. Social differentiation in Russian society has reached its critical point. According to the results of the Higher School of Economics (HSE) study in 2016, the proportion of citizens who do not have enough money to buy clothing or even food was estimated at $44 \%$. The values of the decile and Gini coefficients as generalizing indicators become the evidence of negative trends in the social sphere.

Socially differentiated approach to individual income taxation is a component of Russia's economic policy. It is necessary to return to the progressive scale in this area. The discussion on the flat taxation scale abolition (2001) is of permanent nature and requires a progressive solution.
During the restoration of the USSR tax system there was no Tax Code, but a legislative base was created. By early 1920 the Presidium of the All-Russian Central Executive Committee and the Council of People's Commissars were vested with the Legislative Power except for the Congresses of the RCP (B) and the All-Russian Central Executive Committee. The introduction and abolition of taxes were regulated by decrees of the Soviet government adapted to the conditions of the financial and economic instability of the country.

The tax legislation of the Russian Federation was adopted in December 1991 required adjustments constantly. Many years work in this area resulted in creation of the Tax Code of the Russian Federation (1999 - part 1, 2001 - part 2)

Throughout the period of the Tax Code of the Russian Federation existence, it is accompanied by constant amendments, adjustments, and changes, which gives an unstable character to the tax system of the country and causes discontent of all participants of the taxation process. To break negative business expectations D. A. Medvedev emphasizes the need to ensure predictability in tax policy.

It is necessary to transform the Tax Code of the Russian Federation in order to adapt it to the forthcoming transformation of the country's economy. The main result is the stability of the Tax Code, which will serve as a reliable basis for tax policy as an integral part of effective budget policy formation during the transition to a new model of the economy.

The thought of prof. L. N. Yurovsky (1927) is perceived as highly modern: with the solution of financial problems, "the issues of rationalization of production, increase of labor productivity, development of export branches of the national economy, and agriculture as the main one, will then become even clearer as the main issues of economic policy" [6, p. 472].

\section{References}

1. Menkov F. A. Osnovnye nachala finansovoi nauki [Basic principles of financial science]. Moscow, Financial and Economic Bureau NKF the USSR, 1924. Issue 1, 130 p.

2. Sokolnikov G. Ya. Report at the 10th All-Russian Congress of Soviets on December 25, 1922. In Sokolnikov G. Ya. Novaya finansovaya politika. Na puti $k$ tverdoi valyute [New financial policy. On the way to hard currency]. Moscow, Nauka Publ., 2003. Pp. 104-122. (In Russ.). 
3. Sokolnikov G. Ya. Report on Session III of the CEC of the USSR on November 9, 1923. In Sokolnikov G. Ya. Novaya finansovaya politika. Na puti $k$ tverdoi valyute [New financial policy. On the way to hard currency]. Moscow, Nauka Publ., 2003. Pp. 129-155. (In Russ.).

4. Gordin A. M. Expenses of the unified state budget. In Sokolnikov G. Ya. (ed.) Osnovy finansovoi sistemy SSSR [Fundamentals of the financial system of the USSR]. Moscow, Gosfinizdat Publ., 1930. Pp. 20-27. (In Russ.)

5. Bryukhanov N. P. Bulletin of Finance, 1927, no. 11.

6. Yurovsky L. N. Denezhnaya politika Sovetskoi vlasti (1917-1927) [Monetary policy of the Soviet Power (1917-1927)]. Moscow, Ekonomika Publ., 2008. 586 p.

7. Hansel P. P. Pryamye nalogi. Ocherk teorii i praktiki [Direct taxes. Essays on theory and practice]. Leningrad, Finizdat, 1927. 108 p.

8. Mikeladze P. V. Kosvennye nalogi [Indirect taxes]. Leningrad, Finizdat Publ., 1927. 124 p.

9. Hansel P. P. Sistema nalogov Sovetskoi Rossii [The system of taxes in Soviet Russia]. Moscow, Leningrad, Ekonomicheskaya zhizn Publ., 1924. 86 p.

10. Genzel P. P. Nalogooblozhenie v Rossii vo vremena nepa [Taxation in Russia at the time of NEP]. Moscow, Society of Merchants and Industrialists of Russia Publ., 2006. 384 p.

11. Bryukhanov N. P. Byudzhet 1927/28 g. i osnovnye zadachi nashego ekonomicheskogo stroitel'stva [The budget of 1927-28 and the main tasks of our economic construction]. Moscow, Financial Publishing House of the USSR NKF, 1928. 96 p.

12. Kulisher I. M. Issues of tax policy. Finansy i denezhnoe obrashchenie v Sovetskoi Rossii [Finance and Money Circulation in Soviet Russia]. Moscow, Leningrad, Petrograd Publ., 1924. Pp. 91-99. (In Russ.).

13. Pushkareva V. M. Nalogovaya sistema Soyuza SSR (1921-1930) [The tax system of the USSR (1921-1930)]. Moscow, Vuzovskii uchebnik Publ., INFRA-M Publ., 2011. 196 p.

14. Tverdokhlebov V. N. Novye finansovye problemy (1914-1923) [The newest financial problems (1914-1923)]. Petrograd, Academia Publ., 1923. 160 p.

15. Sokolnikov G. Ya. Report at the Moscow District Financial Meeting on June 2, 1924. In Sokolnikov G. Ya. Novaya finansovaya politika. Na puti $k$ tverdoi valyute [New financial policy. On the way to hard currency]. Moscow, Nauka Publ., 2003. Pp. 185-197. (In Russ.).

16. Reingold I. I. The financial policy of NEP. In Sokolnikov G. Ya. (ed.) Osnovy finansovoi sistemy SSSR [Fundamentals of the financial system of the USSR]. Moscow, Gosfinizdat Publ., 1930, pp. 56-61. (In Russ.).

17. Bogolepov M. I. The state budget and its prospects. Finansy i denezhnoe obrashchenie $v$ Sovetskoi Rossii [Finance and Money Circulation in Soviet Russia]. Moscow, Leningrad, Petrograd Publ., 1924. Pp. 67-73. (In Russ.).

18. Medvedev D. A. Social and Economic Development of Russia: Finding New Dynamics. Issues of Economics, 2016, no. 10, pp. 5-30. (In Russ.).

AUTHOR Valentina M. Pushkareva - Doctor of Economics, Professor, Institute of Economics and Entrepreneurship, Moscow, Russia (13 Bekhterev St., 115477, Moscow, Russia); e-mail: inep_oz@list.ru

ИНФОРМАЦИЯ ОБ АВТОРЕ Пушкарева Валентина Максимовна - доктор экономических наук, профессор, Институт экономики и предпринимательства, г. Москва, Россия (115477, г. Москва, ул. Бехтерева, 13); e-mail: inep_oz@list.ru

FOR CITATION Pushkareva V. M. Tax policies and practices of money tax revival in Soviet Russia (1921-1924) and their relevance. Journal of Tax Reform, 2017, vol. 3, no. 1, pp. 52-62. DOI: $10.15826 /$ jtr.2017.3.1.031

ДЛя ЦИТИРОВАНИЯ Пушкарева В. М. Налоговая политика и практика возрождения денежных налогов в Советской России (1921-1924) и их актуальность / В. М. Пушкарева // Journal of Tax Reform. - 2017. - Т. 3, № 1. C. 52-62. - DOI: $10.15826 /$ jtr.2017.3.1.031

ARTICLE INFO Received January 14, 2017; accepted March 2, 2017

ИНФОРМАЦИЯ О СТАТЬЕ Дата поступления 14 января 2017 г.; дата принятия к печати 2 марта 2017 г. 